\title{
The roles of melanin-concentrating hormone in energy balance and reproductive function: are they connected?
}

\author{
Jane Naufahu, Adam D Cunliffe ${ }^{1}$ and Joanne F Murray \\ Department of Human and Health Sciences, School of Life Sciences, University of Westminster, 115 New Cavendish \\ Street, London W1W 6UW, UK and ${ }^{1}$ Department of Applied Science, London Southbank University, 103 Borough \\ Road, London SE1 OAA, UK
}

Correspondence should be addressed to J Naufahu; Email: j.naufahu2@westminster.ac.uk

\begin{abstract}
Melanin-concentrating hormone (MCH) is an anabolic neuropeptide with multiple and diverse physiological functions including a key role in energy homoeostasis. Rodent studies have shown that the ablation of functional $\mathrm{MCH}$ results in a lean phenotype, increased energy expenditure and resistance to diet-induced obesity. These findings have generated interest among pharmaceutical companies vigilant for potential anti-obesity agents. Nutritional status affects reproductive physiology and behaviours, thereby optimising reproductive success and the ability to meet energetic demands. This complex control system entails the integration of direct or indirect peripheral stimuli with central effector systems and involves numerous mediators. A role for $\mathrm{MCH}$ in the reproductive axis has emerged, giving rise to the premise that $\mathrm{MCH}$ may serve as an integratory mediator between those discrete systems that regulate energy balance and reproductive function. Hence, this review focuses on published evidence concerning i) the role of $\mathrm{MCH}$ in energy homoeostasis and ii) the regulatory role of $\mathrm{MCH}$ in the reproductive axis. The question as to whether the $\mathrm{MCH}$ system mediates the integration of energy homoeostasis with the neuroendocrine reproductive axis and, if so, by what means has received limited coverage in the literature; evidence to date and current theories are summarised herein.
\end{abstract}

Reproduction (2013) 146 R141-R150

\section{Introduction}

Energy balance is inextricably linked to reproduction: the ability to monitor both internal and external energy availability and consequently to modulate reproductive behaviours confers a species-wide reproductive advantage (Schneider 2004). In times of energy scarcity, survival of the individual takes precedence over reproductive activities, which bear high energy and nutrient demands. Reproductive disturbances may be evident on either side of the energy balance continuum. It is well established that low energy availability results in adaptive responses that ultimately suppress ovarian function in both humans and female mammals. On the other hand, obesity is also associated with reproductive disorders that may affect both ovarian and neuroendocrine functions (Pasquali et al. 2003, Solorzano et al. 2012).

These reproductive derangements both in the undernourished and in the obese are unsurprising from an evolutionary viewpoint that propounds survival of the fittest. Hence, those mechanisms that control reproductive function and nutritional status must be functionally linked (Schneider 2004). Nevertheless, in mammals these links are complex and incompletely understood. However, it is evident that there are myriad hormonal and neuropeptide interactions that ultimately modify gonadotrophin-releasing hormone (GNRH) activity in response to metabolic cues (Evans \& Anderson 2012). One neuropeptide that participates in energy homoeostasis but has received comparatively little attention within the reproductive context is melanin-concentrating hormone $(\mathrm{MCH})$.

Originally characterised as a circulating hormone modulating the skin colour of teleost fish (Kawauchi et al. 1983), mammalian $\mathrm{MCH}$ was subsequently identified in rat hypothalamic tissue (Vaughan et al. 1989). The majority of anatomical work has been undertaken in the rodent, in which the neuropeptide is expressed primarily, though not exclusively, in the lateral hypothalamic area (LHA) and the rostral zona incerta/ incertohypothalamic area (IHy) (Bittencourt et al. 1992, Sita et al. 2007, Bittencourt 2011): two areas known to be critically involved in the regulation of feeding behaviours. The orexigenic properties of $\mathrm{MCH}$ were first proposed in 1996 (Qu et al. 1996), although the findings of a number of subsequent studies suggest that the anti-obesogenic effects of $\mathrm{MCH}$ antagonism are mediated through its effects on appetite regulation, secondary to its effects on energy expenditure and 
altered metabolism (Shimada et al. 1998, Chen et al. 2002, Marsh et al. 2002, Segal-Lieberman et al. 2003).

The physiological functions of $\mathrm{MCH}$ are not restricted to energy metabolism. Of particular interest to this review are the effects of $\mathrm{MCH}$ on the female reproductive axis. To date, the known effects are largely those associated with the central effects of $\mathrm{MCH}$ on the regulation of luteinising hormone $(\mathrm{LH})$ release (Gonzalez et al. 1997, Murray et al. 2000a, 2006, Williamson-Hughes et al. 2005). It must be noted that while evidence implicating $\mathrm{MCH}$ in the central control of consummatory behaviours and energy expenditure is robust, the role of $\mathrm{MCH}$ in the reproductive axis is less well corroborated. For example, although Pmchknockout (k/o) mice are fertile (Shimada et al. 1998, Marsh et al. 2002, Alon \& Friedman 2006, Adams et al. 2011), there are no reports in which the efficiency of reproductive function has been fully investigated. Hence, while $\mathrm{MCH}$ appears not to be an absolute requirement for normal reproduction, its role(s) as a mediator and/or modulator are as yet ambiguous (see part 3). Evidence to date indicates that the physiological significance of $\mathrm{MCH}$ in reproduction may be auxiliary to its better-characterised role: further investigation is required to confirm or deny such an assertion. Hence, this review focuses on published evidence concerning the dual roles of $\mathrm{MCH}$ in these discrete yet overlapping systems that modulate energy balance and reproductive function.

\section{Part 1: $\mathrm{MCH}$, appetite regulation and energy expenditure}

The pharmaceutical industry is currently very interested in targeting the $\mathrm{MCH}$ system as a therapeutic in the treatment of obesity because of its regulatory role in feeding behaviours and energy expenditure, though the development of such a compound has not been without challenges (Mendez-Andino \& Wos 2007, Hogberg et al. 2012). Of particular relevance are studies that report that the deletion of either the Pmch gene or $\mathrm{MCH}$ receptor (Mchr1) results in resistance to diet-induced obesity (Chen et al. 2002, Kokkotou et al. 2005, Mashiko et al. 2005). Although two MCH receptor subtypes have been identified in humans, rhesus monkeys, dogs and ferrets (designated MCHR1 and MCHR2), research to date has focused on MCHR1, since functional MCHR2 is not conserved in rodents or rabbits (Tan et al. 2002). Due to this evolutionary divergence, the relevance of rodent models to the study of $\mathrm{MCH}$ reproductive interactions may be questioned; however, limited research indicates that the most likely physiological roles for MCHR2 are concerned with the modulation of feeding behaviours (Rodriguez et al. 2001, Wang et al. 2001, Ghoussani et al. 2007). A summary of key results is presented in Table 1. The behavioural and metabolic effects of $\mathrm{MCH}$ on energy homeostasis may be summarised as follows:

\section{Appetitive behaviours}

Accumulating evidence from behavioural and anatomical studies supports a role for $\mathrm{MCH}$ activity in the hedonic aspects of feeding. Anatomically, central $\mathrm{MCH}$ is well placed to integrate energy balance with food reward since the LHA is highly innervated by neuronal input from the nucleus accumbens (NAc), an integral component of the brain's reward circuitry (Grace et al. 2007, Mahler et al. 2007). It is proposed that the up-regulation of dopamine promotes reward-seeking via neuronal activation of the NAc, which ultimately stimulates feeding by disinhibition of the LHA (for review, see Morton et al. (2006)). Food intake, though not energy expenditure, is increased or decreased after injections of $\mathrm{MCH}$ agonists or MCHR1 antagonists respectively into the NAc shell (Georgescu et al. 2005, Guesdon et al. 2009). Anatomically, this area is densely populated by the $\mathrm{MCH}$ receptor, as are areas involved in olfaction and gustation (Kokkotou et al. 2001, Saito et al. 2001). A critical role for $\mathrm{MCH}$ in olfaction was proposed by Adams et al. (2011), who reported that Pmch-k/o mice demonstrated impaired food-seeking behaviours. The infusion of $\mathrm{MCH}$ resulted in increased fatty food, alcohol, sucrose and saccharin intake (Gomori et al. 2003, Duncan et al. 2005, Sakamaki et al. 2005, Furudono et al. 2006). The antagonism of the $\mathrm{MCH}$ receptor via the i.c.v. or i.p. route reduced the consumption of highly palatable or high-fat food (Morens et al. 2005, Nair et al. 2009), whilst the

Table 1 Summary of results of key mammalian energy balance MCH studies.

\begin{tabular}{|c|c|c|c|c|}
\hline $\begin{array}{l}\text { Availability } \\
\text { of } \mathrm{MCH}\end{array}$ & Experimental intervention & Effect on food intake & $\begin{array}{l}\text { Effect on locomotor activity } \\
\text { and energy expenditure } \\
\text { (EE)/metabolic rate (MR) }\end{array}$ & $\begin{array}{l}\text { Effect on body weight (BW), } \\
\% \text { fat mass and \% lean mass }\end{array}$ \\
\hline Increased & $\begin{array}{l}\text { Pharmacological/dietary } \\
\text { Genetic manipulation }\end{array}$ & $\begin{array}{l}\text { Hyperphagia/no effect } \\
\text { Hyperphagia }\end{array}$ & $\begin{array}{l}\downarrow \text { Locomotor activity } \\
\text { Not reported }\end{array}$ & $\begin{array}{l}\uparrow \mathrm{BW} ; \uparrow \text { fat } \\
\uparrow \mathrm{BW} ; \uparrow \text { fat }\end{array}$ \\
\hline Decreased & $\begin{array}{l}\text { Pharmacological/dietary } \\
\text { Genetic manipulation }\end{array}$ & $\begin{array}{l}\text { Hypophagia/no effect } \\
\text { Hypophagia/no effect/hyperphagia }\end{array}$ & $\begin{array}{l}\text { Not reported } \\
\uparrow \text { Locomotor activity; } \\
\text { a no effect } / \uparrow \mathrm{EE} / \mathrm{MR}\end{array}$ & $\begin{array}{l}\downarrow \text { BW; } \downarrow \text { fat mass } \\
\downarrow \text { BW; } \downarrow \text { fat; no effect } / \uparrow \text { lean } \\
\text { mass }\end{array}$ \\
\hline
\end{tabular}

Whilst manipulation of the availability of $\mathrm{MCH}$ has variable effects on food intake, the effects on locomotor activity/EE/MR and BW/\% fat mass/\% lean mass are consistent.

${ }^{\mathrm{a}}$ Some effects were observed in males but not in females. 
administration of a MCHR1 antagonist via i.p. injection resulted in reduced sucrose, though not saccharin, selfadministration (Karlsson et al. 2012). By contrast, hindbrain administration of $\mathrm{MCH}$ produced no increase in sucrose, saccharin, food or water intake (Zheng et al. 2005, Baird et al. 2008). Therefore, it would appear that the orexigenic properties of $\mathrm{MCH}$ require forebrain input and that the $\mathrm{MCH}$ response to palatable food is related to the nutritive value of the food as well as to the hedonic aspects of feeding.

\section{Consummatory behaviours}

In rodents, the $\mathrm{MCH}$ system appears to have the capacity to strongly affect feeding behaviours. Hyperphagia or hypophagia can be induced by manipulating the availability of physiological hypothalamic $\mathrm{MCH}$ concentrations. While increased availability results in hyperphagia (Ludwig et al. 2001, Gomori et al. 2003, Santollo \& Eckel 2008), decreased availability can result in either hyperphagia (Chen et al. 2002, Marsh et al. 2002) or hypophagia (Mashiko et al. 2005, Kowalski et al. 2006). This discrepancy may be attributed to the use of either a genetic or pharmacological rodent model. In pharmacological models, antagonism of MCHR1 resulted in reduced body weight, fat mass and food intake, whereas in genetic models although body weight was decreased or unchanged, food intake in some studies was increased. Compensatory hyperphagia in response to reduced adiposity has been proposed as the cause of increased consummatory behaviours in some Mchr1-k/o rodents; this is suggestive of some developmental adaptation in genetic models (for a review, see Pissios (2009)). Therefore, an important distinction appears to be that in pharmacological models altered feeding behaviours are largely responsible for the resultant phenotype, while in genetic models altered energy expenditure accounts for changes in phenotype as feeding behaviours may remain unaltered, increased or decreased (Pissios 2009; Table 1). MCH treatment also seems to be able to affect meal size, which is increased following the administration of $\mathrm{MCH}$ (Santollo \& Eckel 2008) or decreased following the antagonism of the MCH receptor (Kowalski et al. 2006).

\section{Energy expenditure}

A putative role for $\mathrm{MCH}$ in energy conservation has been validated by findings from genetic studies that have consistently shown that the ablation of functional hypothalamic $\mathrm{MCH}$ results in increased energy expenditure and, in some cases, increased locomotor activity (Shimada et al. 1998, Marsh et al. 2002, Segal-Lieberman et al. 2003, Jeon et al. 2006). As noted above, this phenomenon does not occur in pharmacological models. Furthermore, in some studies, elevated energy expenditure was observed in males only (Chen et al. 2002, Alon \& Friedman 2006). In one study, locomotor activity was decreased following $\mathrm{MCH}$ administration (Santollo \& Eckel 2008). Interestingly, increased energy expenditure resulting from the decreased availability of physiological hypothalamic $\mathrm{MCH}$ may be accompanied by either hyperphagia or hypophagia. Whether these consummatory behaviours are compensation driven (i.e. increased ingestion to compensate for increased energy output) or a result of reduced $\mathrm{MCH}$-induced food intake is not known.

A lack of consistency in terms of the effect of $\mathrm{MCH}$ administration/ablation on feeding behaviours contrasts with the reported uniformity of its effects on energy expenditure (Table 1). In those studies where functional $\mathrm{MCH}$ or its receptor was ablated, all the animals demonstrated increased energy expenditure (although some sexual dimorphism was observed) resulting from increased metabolic rate, increased locomotor activity or both. The characteristic lean phenotype induced by functional $\mathrm{MCH}$ ablation is noteworthy since this property appears to be atypical of other orexigenic mediators such as orexins (Hara et al. 2005), neuropeptide $\mathrm{Y}$ (NPY) and agouti-related protein (AgRP; for reviews, see Lin et al. (2004) and Flier (2006)) and serves to underline the distinctive role of $\mathrm{MCH}$ in energy conservation.

\section{Part 2: $\mathrm{MCH}$ and reproductive function}

While the orexigenic effects of $\mathrm{MCH}$ have been well documented, reports concerning the role of $\mathrm{MCH}$ in the reproductive axis have been less prolific.

Over the last decade, several groups have investigated the potential role of $\mathrm{MCH}$ in the regulation of $\mathrm{LH}$ release, either directly at the level of the pituitary or indirectly via the stimulation of hypothalamic GNRH: the focus of this review is the modulatory role of $\mathrm{MCH}$ in the hypothalamic regulation of the reproductive axis by GNRH. Anatomically, this is plausible since various studies in female rodents have reported the close apposition of $\mathrm{MCH}$ fibres to hypothalamic GNRH neurones (Smith \& Grove 2002, Williamson-Hughes et al. 2005, Wu et al. 2009), and Mchr1 mRNA has been detected in GNRH neurones (Williamson-Hughes et al. 2005). Approximately $85-90 \%$ of GNRH neurones were reportedly in contact with $\mathrm{MCH}$-immunopositive projections (Williamson-Hughes et al. 2005). This is in agreement with a study, albeit in male mice, that reported that $86 \%$ of hypothalamic GNRH neurones were in close apposition with $\mathrm{MCH}$-immunoreactive fibres (Ward et al. 2009). Some anatomical overlap was also observed between $\mathrm{MCH}$-immunoreactive projections and GNRH neuroterminals in the median eminence (Ward et al. 2009). In vitro Mchr1 mRNA has been detected in GT1-7 cell lines (mouse cell model of hypothalamic GNRH neurones) (Yang et al. 2005), although one can speculate 
about the physiological relevance of this type of immortalised cell line and hence this observation.

Early work indicated a stimulatory role for $\mathrm{MCH}$ on $\mathrm{LH}$ secretion when it was injected into the hypothalamic medial preoptic area (mPOA) or median eminence of oestrogen-treated, ovariectomised rats (Gonzalez et al. 1997, Murray et al. 2000a). As has been shown for other neuropeptides (e.g. orexin A: Small et al. (2003)), subsequent studies indicated that whether $\mathrm{MCH}$ is stimulatory or inhibitory to $\mathrm{LH}$ release is dependent on both the site of administration and the endocrine milieu of the rat model (Fig. 1). LH release was stimulated by $\mathrm{MCH}$ administration into the rostral POA (rPOA) or mPOA but not into the IHy of a rat model with low circulating concentrations of LH. Conversely, the same treatment blocked the customary surge-like release of $\mathrm{LH}$ when administered into the $\mathrm{IHy}$ of a rat model primed for such release, though it had no effect when administered into the rPOA or mPOA (Murray et al. 2006). However, injection into the third ventricle using a different rat model inhibited LH release (Tsukamura et al. 2000). These two studies, which appear to have conflicting results, may in fact be in broad agreement, since it was proposed that an i.c.v. injection into the third ventricle could reach the rostromedial $\mathrm{IHy}$ and thereby inhibit LH release (Murray et al. 2006). In vitro GNRH release from hypothalamic explants was stimulated following incubation with $\mathrm{MCH}$, but only in oestrogen-primed explants (Murray et al. 2006).

While there is evidence that $\mathrm{MCH}$ may modulate $\mathrm{LH}$ release indirectly via its actions on hypothalamic GNRH, other studies support a role for $\mathrm{MCH}$ acting directly at the level of the pituitary. The release of both $\mathrm{LH}$ and $\mathrm{FSH}$ from pituitary explants was stimulated by low concentrations of $\mathrm{MCH}$, but only when the pituitaries were removed during proestrous (Chiocchio et al. 2001). Furthermore, the median eminence is highly innervated by MCH neuronal projections (Bittencourt et al. 1992, Bittencourt 2011). Although the specific trophic cell types were not described, the detection of MCHR1 in both human and rodent pituitary tissue suggests direct effect(s) of MCH on pituitary function (Saito et al. 1999, Takahashi et al. 2001, Segal-Lieberman et al. 2006).

Ovarian steroid feedback is a vital component of normal reproductive physiology. Conjecture that an oestrogen-sensitive mechanism may be involved in the regulation of Pmch expression has been investigated. Murray et al. (2000b) reported that oestrogen treatment inhibited the expression of prepro- $\mathrm{MCH}$ cell bodies specifically in the IHy of ovariectomised female rats; however, no difference in prepro- $\mathrm{MCH}$ expression was detected in intact rats at either proestrus or dioestrus (Murray et al. 2000b). The administration of $17 \beta$-oestradiol depressed hypothalamic Pmch gene

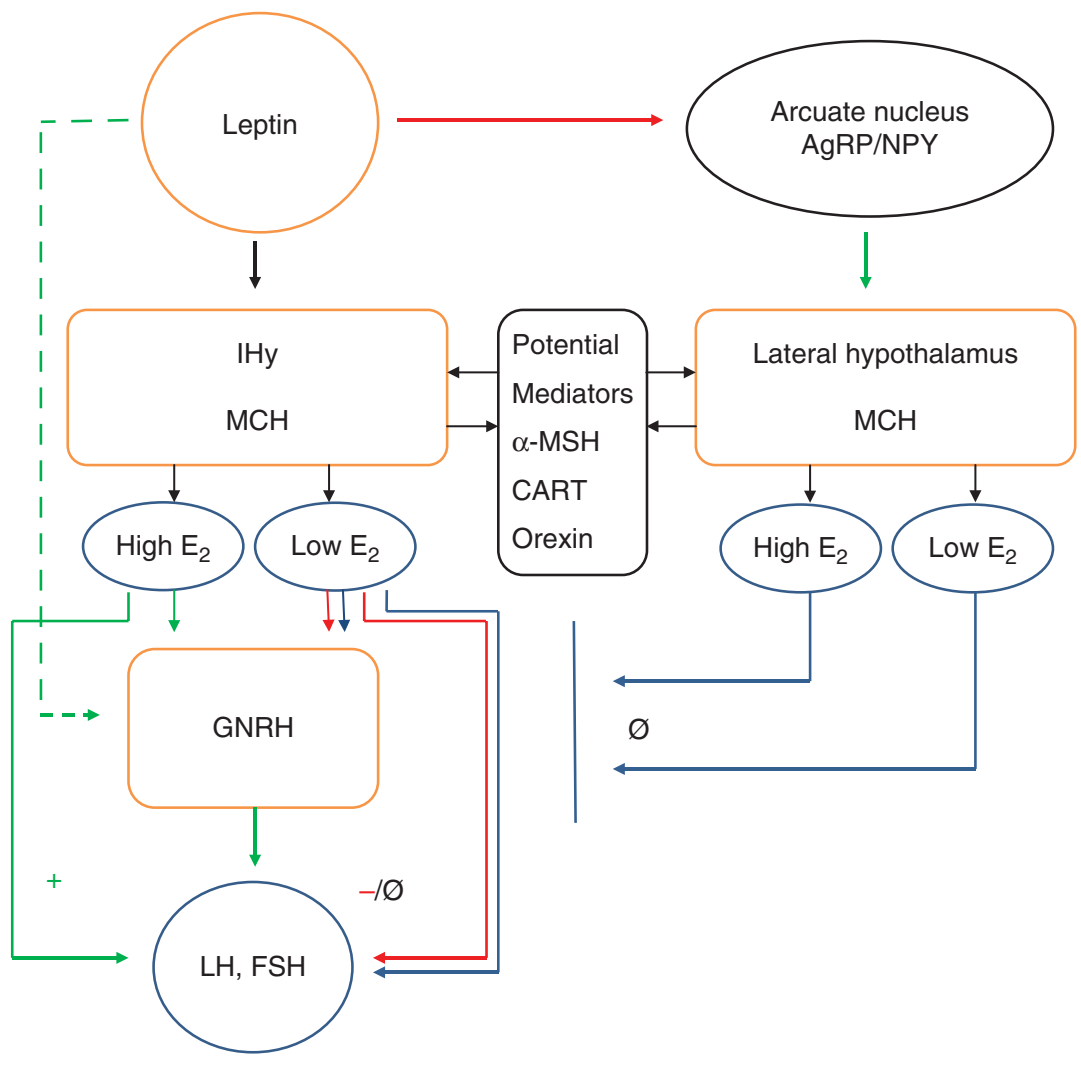

Figure 1 Distinct $\mathrm{MCH}$ neuronal populations in the LHA receive peripheral input from leptin via orexigenic AgRP/NPY neurones in the arcuate nucleus. LHA MCH neurones communicate with $\mathrm{MCH}$ neurones in the IHy directly or indirectly via inter-neurones (examples of potential mediators are given). The IHy $\mathrm{MCH}$ neurones exert stimulatory or inhibitory effects on GNRH, LH and FSH depending on the presence or absence of oestrogen. There is no evidence to date that the $\mathrm{MCH}$ neuronal populations of the LHA have a direct role in the reproductive axis, while there is evidence that the $\mathrm{MCH}$ cell bodies of the IHy may modulate reproductive function (e.g. electrolytic and chemical lesioning of the IHy disrupts the oestrous cycle: MacKenzie et al. (1988)). Red arrows, inhibitory; green arrows, stimulatory; blue arrows, no effect; $\varnothing$, no effect; $\alpha$-MSH, $\alpha$-melanocytestimulating hormone; CART, cocaine-andamphetamine-related transcript. IHy, rostral zona incerta/incertohypothalamic area. 
expression in male rats (Mystkowski et al. 2000) and hypothalamic PMCH protein expression in female rats (Santollo \& Eckel 2013). In ovariectomised primates, an increase in hypothalamic immunoreactive $\mathrm{MCH}$ and immunoreactive neuropeptide $\mathrm{E}-\mathrm{I}$ (NEI) concentrations was detected coincidental with the $\mathrm{LH}$ surge $72 \mathrm{~h}$ after injection of oestradiol, however, oestradiol concentrations would have been returning to baseline in these animals. $\mathrm{MCH}$-immunoreactive content was not significantly increased $30 \mathrm{~h}$ after injection when circulating oestradiol concentrations would be elevated, although the authors do describe them as being 'transiently elevated' (Viale et al. 1999).

Pharmacological doses of oestrogen block the increase in hypothalamic PMCH expression customarily induced by caloric restriction (Morton et al. 2004). Here, it should be noted that under conditions of prolonged energy insufficiency, circulating oestrogen concentrations would be typically low. While the presence of rapid signalling (non-genomic) oestrogen receptors has not been discounted, there is no evidence of the expression of oestrogen receptors on hypothalamic MCH neurones (Muschamp \& Hull 2007, Santollo \& Eckel 2013). However, there was considerable anatomical overlap in the distribution of oestrogen receptor-labelled cells and $\mathrm{MCH}$ neurones, suggestive of an indirect regulatory mechanism, possibly via an intermediary neurone or ligand that consequently modulates MCH expression (Muschamp \& Hull 2007, Santollo \& Eckel 2013).

Whilst it would seem that oestrogen treatment is inhibitory to $\mathrm{MCH}$ expression in both males and females, $\mathrm{MCH}$ appears to be more effective at exerting its biological effect in the presence of oestrogen. The neurones that $\mathrm{MCH}$ innervates are therefore hypothesised to be oestrogen-sensitive. $\mathrm{MCH}$ may directly innervate GNRH neurones which express ESR2 (ER $\beta$ ) (Herbison \& Pape 2001), and/or indirectly via an interneurone that is both $\mathrm{MCH}$ and oestrogen sensitive and in turn acts on GNRH. Clearly, the neurocircuitry controlling the hypothalamic-pituitary-gonadal axis is complex and other neuromodulators are known to be involved: leptin, serotonin, dopamine, kisspeptin and NEI have all, for example, been reported to stimulate gonadotrophin release (MacKenzie et al. 1984, Vitale et al. 1993, Yu et al. 1997, Messager et al. 2005, Attademo et al. 2006). Precisely where MCH fits into this neurocircuitry is yet to be defined, and the proposed indirect effects of $\mathrm{MCH}$ on GNRH via other neuronal populations will be discussed further.

While understanding of the field of kisspeptin physiology is evolving, results of a recent study advocate an inhibitory role for $\mathrm{MCH}$ in the reproductive axis via the inhibition of kisspeptin-sensitive GNRH neurones. Electrophysiological recordings demonstrated not only that $\mathrm{MCH}$ exerted strong inhibitory effects on a subpopulation of GNRH neurones, but also that the excitatory effect of kisspeptin on GNRH was completely blocked by $\mathrm{MCH}$ (Wu et al. 2009). In agreement with earlier work in rodents (Williamson-Hughes et al. 2005, Ward et al. 2009), $\mathrm{MCH}$-ir fibres were also observed in close apposition with GNRH-GFP neurones in mice (Ward et al. 2009, Wu et al. 2009). These results are supportive of a modulatory role for $\mathrm{MCH}$ at the level of GNRH and add credence to the proposal that the $\mathrm{MCH}$ system may act to inhibit reproductive function under conditions of energy insufficiency, when $\mathrm{MCH}$ expression is up-regulated. It should be noted that prepubertal animals were used; therefore, in the absence of oestrogen, a stimulatory effect would not be expected.

Neurokinin B (NKB) is a tachykininergic neuropeptide that has recently been implicated as a critical constituent of normal reproductive biology (Topologlu et al. 2009). In various mammalian species, NKB is co-expressed in the arcuate nucleus (ARC) with kisspeptin and dynorphin (DYN) (Goodman et al. 2007, Wakabayashi et al. 2010), an inhibitory opiod peptide. There is a substantial body of evidence to support the proposal that this trio of ARC peptides known as KNDy are involved in the pulsatile release of GNRH (for a review, see Rance et al. (2010)). However, much exploratory work is required to understand the regulatory network and mechanisms of action of this circuitry. Of interest to this review is the fact that the neurokinin B receptor (TACR3(NK3)) is highly expressed in a subpopulation of $\mathrm{MCH}$ neurones that also express the anorexigenic cocaineand-amphetamine-regulated transcript (CARTPT (CART); Griffond et al. 1997, Cvetkovic et al. 2004). Tachykininergic innervation of the ' $\mathrm{MCH}$-containing area' (i.e. the LHA and rostromedial $\mathrm{IHy}$ ) is extensive and complex (Cvetkovic et al. 2003). It has been hypothesised that $\mathrm{MCH}$ may be involved in reproductive or defensive behaviours since the most medial $\mathrm{MCH}$ cell bodies lie within pathways forming circuits regulating the expression of such behaviours (Thompson et al. 1996, Cvetkovic et al. 2003). On the other hand, only one NKB retrogradely labelled neurone was detected in the ARC following iontophoretic injection into the rostromedial IHy (Cvetkovic et al. 2003). Further work is required, but it is tempting to speculate that a subpopulation of $\mathrm{MCH}$ neurones that also express CARTPT may participate in a circuitry regulating both reproductive function and energy balance via tachykininergic stimulation.

\section{Part 3: $\mathrm{MCH}$, energy balance and fertility}

Nutritional status affects reproductive physiology, and in many mammals reproductive behaviours, thereby optimising both reproductive success and the ability to meet energetic demands. The complex control system entailing the integration of direct or indirect peripheral stimuli with central effector systems involves numerous hormonal and chemical mediators. Neuropeptides, such as $\mathrm{MCH}$, may act in this domain in one of the following ways: i) as 
mediators between feeding behaviours and reproductive function (i.e. when variability in metabolic fuel availability induces altered hormonal response and the consequent modulation of feeding behaviours and reproductive function) and ii) as modulators affecting the availability of oxidisable fuels, thereby influencing reproductive behaviours (Schneider 2004). Though $\mathrm{MCH}$ is active in both the ingestive and reproductive contexts, investigation into the metabolic pathways through which it may integrate these dual functions has been limited. The tendency to favour male models in energy balance research (e.g. Ludwig et al. 2001, Segal-Lieberman et al. 2003, Mashiko et al. 2005, Bjursell et al. 2006) and female models in reproductive studies (e.g. Murray et al. 2000b, Garcia et al. 2003, Williamson-Hughes et al. 2005, Messina et al. 2006) may be problematic for intergender extrapolation of results. In metabolic studies, some sexual dimorphism has been reported. For example, increased energy expenditure was observed in both male Mchr1-k/o and male transgenic mice with temporal loss of $\mathrm{MCH}$, though not in their female counterparts (Chen et al. 2002, Alon \& Friedman 2006). To date, the role of $\mathrm{MCH}$ in male reproductive physiology has been largely neglected. Since in most species the energy cost of procreation for females far exceeds that for males, a potential gender difference in $\mathrm{MCH}$ action would merit investigation.

As discussed earlier, $\mathrm{MCH}$ seems to be stimulatory in the reproductive axis only in the presence of oestrogen, while oestrogen appears to be inhibitory to hypothalamic prepro-MCH expression (Murray et al. 2000b, Mystkowski et al. 2000); the latter phenomenon may be a consequence of negative feedback of oestrogen on $\mathrm{MCH}$. Messina et al. (2006) found that oestradiol treatment decreased $\mathrm{MCH}$-induced food intake. Santollo \& Eckel (2008) also reported that both exogenous oestradiol and endogenous oestradiol exert a reductive effect on $\mathrm{MCH}$-induced feeding via decreased meal size. Furthermore, a difference in the magnitude of the orexigenic effects of $\mathrm{MCH}$ between different stages of the oestrous cycle was observed, with these effects being attenuated in oestrous rats (following high oestradiol secretion) compared with dioestrous rats. Males with lower circulating levels of oestradiol exhibited a greater orexigenic response to $\mathrm{MCH}$ infusion than did females. It was thus hypothesised that the characteristic changes in feeding behaviours at different stages of the oestrous cycle in female rats may partly be mediated by altered MCH signalling (Messina et al. 2006). Furthermore, both endogenous and exogenous oestrogen reduced $\mathrm{PMCH}$ and MCHR1 protein expression in cycling and ovariectomised rats (Santollo \& Eckel 2013). In cycling rats, $\mathrm{PMCH}$ expression and serum oestrogen were negatively associated and fewer $\mathrm{MCH}$-ir neurones were detected in proestrous rats than in dioestrous and oestrous rats. Hence, the authors propose that cyclical oestrogeninduced suppression of feeding behaviours is mediated via reduced hypothalamic PMCH and MCHR1 protein content. This appears to be an indirect effect, however, since in vitro oestrogen failed to alter $\mathrm{PMCH}$ or MCHR1 expression and, in agreement with previous work (Muschamp \& Hull 2007), MCH and ESR1 (ER $\alpha$ ) were not co-localised, although $\mathrm{MCH}$-ir and $\mathrm{ER} \alpha$-ir neurones were detected in proximity. Hence, it could be argued that $\mathrm{MCH}$ acts as a modulator in these scenarios linking female reproductive physiology with ingestive behaviours, since in the presence of oestrogen feeding behaviours are suppressed; therefore, energetic resources may be directed towards reproductive behaviours. Conversely, in the absence of oestrogen (typically under conditions of energy restriction), $\mathrm{MCH}$ does not stimulate the reproductive axis and the energetic emphasis may be directed to the restoration of eubalance. Clearly, more work is required under normal physiological conditions.

Significantly, the MCH neuronal population is heterogeneous, and a number of subpopulations have been identified based on their topography, co-expression with other neurotransmitter receptors and peptides, axonal pathways, projections to distinct brain regions or time of genesis (Elias \& Bittencourt 1997, Griffond et al. 1997, Bittencourt \& Elias 1998, Bayer et al. 1999, Brischoux et al. 2002, Cvetkovic et al. 2004, Schéle et al. 2012). Hence, it is likely that these discrete populations respond to different stimuli and may act through different pathways. There has been a tendency to overlook these distinctions in research to date, which could be a source of equivocality with regard to the roles of $\mathrm{MCH}$; for example, if a specific subpopulation of $\mathrm{MCH}$ neurones interface with an oestrogen-sensitive mechanism, this may partly explain the phenomenon that $\mathrm{MCH}$ seems to exert its effects only in the presence of oestrogen.

Pregnancy and lactation present considerable physiological challenges to the organism. Lactation, in particular, is characterised by substantially increased energy demands and a marked increase in food intake in rats (Oftedal 2004). Pmch expression was transiently induced in the hypothalamic POA and rostral parts of the paraventricular nucleus of dams 8-21 days postpartum (Knollema et al. 1992). Others have since reported similar results (Sun et al. 2004, Rondini et al. 2010); however, one research group has reported the converse; that is, a decrease in hypothalamic Pmch mRNA expression in pregnant and lactating rats (Garcia et al. 2003). Mice in which a time-dependent ablation of $\mathrm{MCH}$ neurones was orchestrated were not capable of rearing their offspring (Alon \& Friedman 2006). Pmch-k/o mice had smaller, lighter litters with poorer survival rates than wild-type mice (Adams et al. 2011); these studies indicate a role for $\mathrm{MCH}$ in lactation and maternal behaviour. Though Pmch-k/o mice are fertile (Shimada et al. 1998, Alon \& Friedman 2006, Adams et al. 2011), the dubious health of the offspring in the latter study suggests compromised uterine growth and/or postpartum 
development. Anterograde tracer injections in lactating rats revealed dense projections from medial POA neurones to areas involved in the control of gonadotrophin expression and female sexual behaviours (Rondini et al. 2010). Specifically, there was a significant increase in $\mathrm{MCH}$ innervation of the ventrolateral subdivision of the ventromedial nucleus of the hypothalamus and the ventral premammillary nucleus, leading the authors to propose that $\mathrm{MCH}$ may be acting to inhibit reproductive function and behaviours during lactation via this pathway. A further finding that the $\mathrm{MCH}$ neurones of the mPOA co-express the inhibitory GABA-synthesising enzyme glutamic acid decarboxylase provoked the hypothesis that the $\mathrm{MCH} / \mathrm{GABA}$ neurones may inhibit pulsatile LH secretion during lactation (Rondini et al. 2010) via the close apposition of $\mathrm{MCH}$ and NEI terminals to GNRH cell bodies (Smith \& Grove 2002, Williamson-Hughes et al. 2005, Ward et al. 2009, Wu et al. 2009) or via MCHR1, which is co-expressed in a subpopulation of GNRH neurones (Williamson-Hughes et al. 2005). Finally, since the mPOA MCH neurones of female rats were in close apposition to terminals immunoreactive for AgRP, $\alpha$-melanocyte-stimulating hormone and CART, neurobiological regulators clearly implicated in energy balance (Rondini et al. 2010), it could be that the $\mathrm{mPOA}$ is one site where $\mathrm{MCH}$ is active in the integration of ingestive and reproductive behaviours, at least in conditions of negative energy balance that are customary during lactation.

\section{Summary}

The portfolio of the multiple and diverse physiological functions of $\mathrm{MCH}$, both metabolic and behavioural, continues to expand. Over the last two decades, its role as a crucial mediator of energy balance has become apparent. The known activities of $\mathrm{MCH}$ in the reproductive axis are chiefly those associated with the regulation of $\mathrm{LH}$ release and the effect of oestrogen on $\mathrm{MCH}$ expression. $\mathrm{MCH}$ may stimulate or inhibit $\mathrm{LH}$ release depending on oestrogenic milieu, and $\mathrm{MCH}$ expression may be oestrogen-dependent. Furthermore, in female rats, cyclic modulation of feeding behaviours may be partially mediated by altered $\mathrm{MCH}$ signalling. The complexities of the inter-relationship between ingestive and reproductive behaviours are slowly being unravelled, and $\mathrm{MCH}$ is undoubtedly a component of this neurocircuitry, though the extent and scope of its molecular interactions are still being documented. Evidence to date suggests that, in the reproductive context, $\mathrm{MCH}$ is a modulator rather than a primary regulator. However, as the $\mathrm{MCH}$ story unfolds, questions are both answered and posed, and manipulation of the availability of $\mathrm{MCH}$ and its receptor in different animal models has provided some important insights into its physiological relevance.

\section{Declaration of interest}

The authors declare that there is no conflict of interest that could be perceived as prejudicing the impartiality of the review.

\section{Funding}

This research did not receive any specific grant from any funding agency in the public, commercial or not-forprofit sector.

\section{References}

Adams AC, Domouzoglou EM, Chee MJ, Segal-Lieberman G, Pissios P \& Maratos-Flier E 2011 Ablation of the hypothalamic neuropeptide melanin concentrating hormone is associated with behavioural abnormalities that reflect impaired olfactory integration. Behavioural Brain Research 234 195-200. (doi:10.1016/j.bbr.2011.05.039)

Alon T \& Friedman JM 2006 Late-onset leanness in mice with targeted ablation of melanin-concentrating hormone neurons. Journal of Neuroscience 26 389-397. (doi:10.1523/JNEUROSCI.1203-05.2006)

Attademo AM, Rondini TA, Rodrigues BC, Bittencourt JC, Celis ME \& Elias CF 2006 Neuropeptide glutamic acid-isoleucine may induce luteinising hormone secretion via multiple pathways. Neuroendocrinology 83 313-324. (doi:10.1159/000096052)

Baird J-P, Rios C, Loveland JL, Beck J, Tran A \& Mahoney CE 2008 Effects of hindbrain melanin-concentrating hormone and neuropeptide $\mathrm{Y}$ administration on licking for water, saccharin and sucrose solutions. American Journal of Physiology. Regulatory, Integrative and Comparative Physiology 294 R329-R343. (doi:10.1152/ajpregu.00611.2006)

Bayer L, Risold PY, Griffond B \& Fellman D 1999 Rat diencephalic neurones producing melanin-concentrating hormone are influenced by ascending cholinergic projections. Neuroscience 91 1087-1101. (doi:10.1016/ S0306-4522(98)00678-2)

Bittencourt JC 2011 Anatomical organisation of the melanin-concentrating hormone peptide family in the mammalian brain. General and Comparative Endocrinology 172 185-197. (doi:10.1016/j.ygcen.2011. 03.028)

Bittencourt JC \& Elias CF 1998 Melanin-concentrating hormone and neuropeptide El projections from the central hypothalamic area and zona incerta to the medial septal nucleus and spinal cord: a study using multiple removal traces. Brain Research 805 1-19. (doi:10.1016/S00068993(98)00598-8)

Bittencourt JC, Presse F, Arias C, Peto C, Vaughan J, Nahon JL, Vale W \& Sawchenko PE 1992 The melanin-concentrating hormone system of the rat brain: an immuno- and hybridization histochemical characterization. Journal of Comparative Neurology 319 218-245. (doi:10.1002/cne. 903190204)

Bjursell M, Gerdin A-K, Ploj K, Svensson D, Svennson L, Oscarsson J, Snaith M, Tornell J \& Bohlooly-Y M 2006 Melanin-concentrating hormone receptor 1 deficiency increases insulin sensitivity in obese leptin-deficient mice without affecting body weight. Diabetes $\mathbf{5 5}$ 725-733. (doi:10.2337/diabetes.55.03.06.db05-1302)

Brischoux F, Cvetkovic V, Griffond B, Felllman D \& Risold PY 2002 Time of genesis determines projection and neurokinin-3 expression patterns of diencephalic neurons containing melanin concentrating hormone. European Journal of Neuroscience 16 1672-1680. (doi:10.1046/j. 1460-9568.2002.02229.x)

Chen Y, Hu C, Hsu CK, Zhang Q, Bi C, Asnicar M, Hsuing HM, Fox N, Slieker LJ, Yang DD et al. 2002 Targeted disruption of the melaninconcentrating hormone receptor-1 results in hyperphagia and resistance to diet-induced obesity. Endocrinology 143 2469-2477. (doi:10.1210/ en.143.7.2469)

Chiocchio SR, Gallardo MGP, Louzan P, Gutnisky V \& Tramezzani JH 2001 Melanin-concentrating hormone stimulates the release of luteinizing hormone-releasing hormone and gonadotropins in the female rat acting at both median eminence and pituitary levels. Biology of Reproduction 64 1466-1472. (doi:10.1095/biolreprod64.5.1466) 
Cvetkovic V, Poncet F, Fellman D, Griffond B \& Risold PY 2003 Diencephalic neurons producing melanin concentrating hormone are influenced by local and multiple extra hypothalamic tachykininergic projections through the neurokinin 3 receptor. Neuroscience 119 1113-1145. (doi:10.1016/S0306-4522(03)00146-5)

Cvetkovic V, Brischoux F, Jaquemard C, Fellman D, Griffond B \& Risold PY 2004 Characterization of subpopulations of neurons producing melaninconcentrating hormone in the rat ventral diencephalon. Journal of Neurochemistry 91 911-919. (doi:10.1111/j.1471-4159.2004.02776.x)

Duncan EA, Proulx K \& Woods SC 2005 Central administration of melaninconcentrating hormone increases alcohol and sucrose/quinine intake in rats. Alcoholism: Clinical and Experimental Research 29 958-964. (doi:10.1097/01.ALC.0000167741.42353.10)

Elias CF \& Bittencourt JC 1997 Study of the origins of melanin-concentrating hormone and neuropeptide $\mathrm{El}$ immune reactive projections to the periaqueductal gray. Brain Research 55 255-271. (doi:10.1016/S00068993(97)00104-2)

Evans JJ \& Anderson GM 2012 Balancing ovulation and anovulation: integration of the reproductive and energy balance axes by neuropeptides. Human Reproduction Update 18 313-332. (doi:10.1093/ humupd/dms004)

Flier JS 2006 AgRP in energy balance. Will the real AgRP please stand up? Cell Metabolism 3 83-85. (doi:10.1016/j.cmet.2006.01.003)

Furudono Y, Ando C, Yamamoto C, Kobashi M \& Yamamoto T 2006 Involvement of specific orexigenic neuropeptides in sweetener-induced overconsumption in rats. Behavioural Brain Research 175 241-248. (doi:10.1016/j.bbr.2006.08.031)

Garcia MC, Lopez M, Gualillo O, Seoane LM, Dieguez C \& Senaris RM 2003 Hypothalamic levels of NPY, MCH and prepro-orexin mRNA during pregnancy and lactation in the rat: role of prolactin. FASEB Journal 17 1392-1400. (doi:10.1096/fj.02-0933com)

Georgescu D, Sears RM, Hommel JD, Barrot M, Bolanos CA, Marsh DJ, Bednarke MA, Bibb JA, Maratos-Flier E, Nestler EJ et al. 2005 The hypothalamic neuropeptide melanin-concentrating hormone acts in the nucleus accumbens to modulate feeding behaviour and forced-swim performance. Journal of Neuroscience 25 2933-2940. (doi:10.1523/ JNEUROSCI.1714-04.2005)

Ghoussani M, Vatin V, Lecoeur C, Abkevich V, Younus A, Samson C, Wachter C, Heunde B, Tauber M, Tounian A et al. 2007 Genetic study of the melanin concentrating hormone receptor 2 in childhood and adulthood and adulthood severe obesity. Journal of Clinical Endocrinology and Metabolism 92 4403-4409. (doi:10.1210/jc.2006-2316)

Gomori A, Ishihara A, Ito M, Mashiko S, Matsushita H, Yumoto M, Ito M, Tanaka T, Tokita S, Moriya M et al. 2003 Chronic intracerebroventricular infusion of $\mathrm{MCH}$ causes obesity in mice. American Journal of Physiology. Endocrinology and Metabolism 284 E583-E588. (doi:10.1152/ajpendo. 00350.2002)

Gonzalez MI, Baker BI \& Wilson CA 1997 Stimulatory effect of melaninconcentrating hormone on luteinising hormone release. Neuroendocrinology 66 254-262. (doi:10.1159/000127246)

Goodman RL, Lehman MN, Smith JT, Coolen LM, de Oliveira CV, Jafarzadehshirazi MR, Pereira A, Iqbal J, Caraty A, Ciofi P et al. 2007 Kisspeptin neurons in the arcuate nucleus of the ewe express both dynorphin A and neurokinin B. Endocrinology 148 5752-5760. (doi:10.1210/en.2007-0961)

Grace AA, Floresco SB, Goto Y \& Lodge DJ 2007 Regulation of firing of dopaminergic neurons and control of goal-directed behaviours. Trends in Neuroscience 30 220-227. (doi:10.1016/j.tins.2007.03.003)

Griffond B, Ciofi P, Bayerr L, Jacquemard C \& Fellman D 1997 Immunocytochemical detection of the neurokinin B receptor (NK3) on melanin-concentrating hormone $(\mathrm{MCH})$ neurons in rat brain. Journal of Chemical Neuroanatomy 12 183-189. (doi:10.1016/S0891-0618 (96)00200-1)

Guesdon B, Paradis E, Samson P \& Richard D 2009 Effects of intracerebroventricular and intra-accumbens melanin-concentrating hormone agonism on food intake and energy expenditure. American Journal of Physiology. Regulatory, Integrative and Comparative Physiology 296 R469-R478. (doi:10.1152/ajpregu.90556.2008)

Hara J, Yanagisawa M \& Sakurai T 2005 Difference in obesity phenotype between orexin knockout mice and neuron-deficient mice with same genetic background and environmental conditions. Neuroscience Letters 380 239-242. (doi:10.1016/j.neulet.2005.01.046)
Herbison AE \& Pape JR 2001 New evidence for estrogen receptors in gonadotropin-releasing hormone neurons. Frontiers in Neuroendocrinology 22 292-308. (doi:10.1006/frne.2001.0219)

Hogberg T, Frimurer TM \& Sasmal PK 2012 Melanin concentrating hormone receptor 1 (MCHR1) antagonists - still a viable approach for obesity treatment? Bioorganic and Medicinal Chemistry Letters 22 6039-6047. (doi:10.1016/j.bmcl.2012.08.025)

Jeon JY, Bradley RL, Kokkotou EG, Marino FE, Wang X, Pissios P \& MaratosFlier E $2006 \mathrm{MCH}^{-1-}$ mice are resistant to aging-associated increases in body weight and insulin resistance. Diabetes 56 428-434. (doi:10.2337/ diabetes.55.02.06.db05-0203)

Karlsson C, Zook M, Ciccocioppo R, Gehlert DR, Thorsell A, Heilig M \& Cippitelli A 2012 Melanin-concentrating hormone receptor 1 (MCH1-R) antagonism: reduced appetite for calories and suppression of addictivelike behaviours. Pharmacology, Biochemistry and Behaviour 102 400-406. (doi:10.1016/j.pbb.2012.06.010)

Kawauchi H, Kawazoe I, Tsubokawa M, Kishida M \& Baker BI 1983 Characterisation of melanin-concentrating hormone in chum salmon pituitaries. Nature 305 321-323. (doi:10.1038/305321a0)

Knollema S, Brown ER, Vale W \& Sawchenko PE 1992 Novel hypothalamic and preoptic sites of prepro-melanin-concentrating hormone messenger ribonucleic acid and peptide expression in lactating rats. Journal of Neuroendocrinology 4 709-717. (doi:10.1111/j.1365-2826.1992. tb00222.x)

Kokkotou E, Tritos NA, Mastaitis JW, Slieker L \& Maratos-Flier E 2001 Melanin-concentrating hormone receptor is a target of leptin action in the mouse brain. Endocrinology 142 680-686. (doi:10.1210/en.142. 2.680)

Kokkotou E, Jeon JY, Wang X, Marino FE, Carlson M, Trombly DJ \& Maratos-Flier E 2005 Mice with MCH ablation resist diet-induced obesity through strain-specific mechanisms. American Journal of Physiology. Regulatory, Integrative and Comparative Physiology 298 R117-R124. (doi:10.1152/ajpregu.00861.2004)

Kowalski TJ, Spar BD, Weig B, Farley C, Cook J, Ghibaudi L, Fried S, O'Neill K, Del Vecchio RA, McBriar M et al. 2006 Effects of a selective melanin concentrating hormone 1 receptor antagonist on food intake and energy homeostasis in diet-induced obese mice. European Journal of Pharmacology 535 182-191. (doi:10.1016/j.ejphar.2006.01.062)

Lin S, Boey D \& Herzog H 2004 NPY and Y receptors: lessons from transgenic and knockout models. Neuropeptides 38 189-200. (doi:10. 1016/j.npep.2004.05.005)

Ludwig DS, Tritos NA, Mastaitis JW, Kulkarni R, Kokkotou E, Elmquist J, Lowell B, Flier JS \& Maratos-Flier E 2001 Melanin-concentrating hormone overexpression in transgenic mice leads to obesity and insulin resistance. Journal of Clinical Investigation 107 379-386. (doi:10.1172/ JCl10660)

MacKenzie FJ, Hunter AJ, Daly C \& Wilson CA 1984 Evidence that the dopaminergic incerto-hypothalamic tract has a stimulatory effect on ovulation and gonadotrophin release. Neuroendocrinology 39 289-295. (doi:10.1159/000123995)

MacKenzie FJ, James MD \& Wilson CA 1988 Changes in dopamine activity in the zona incerta (ZI) over the rat oestrous cycle and the effect of lesions of the ZI on cyclicity: further evidence that the incerto-hypothalamic tract has a stimulatory role in the control of $\mathrm{LH}$ release. Brain Research 444 75-78. (doi:10.1016/0006-8993(88)90915-8)

Mahler SV, Smith KS \& Berridge KC 2007 Endocannabinoid hedonic hotspot for sensory pleasure: anandamide in nucleus accumbens shell enhances "liking" of a sweet reward. Neuropsychopharmacology 32 2267-2278. (doi:10.1038/sj.npp.1301376)

Marsh DJ, Weingarth DT, Novi DE, Chen HY, Trumbauer ME, Chen AS, Guan XM, Jiang MM, Feng Y, Camacho RE et al. 2002 Melaninconcentrating hormone-1 deficient mice are lean, hyperactive and hyperphagic and have altered metabolism. PNAS 99 3240-3245. (doi:10.1073/pnas.052706899)

Mashiko S, Ishihara A, Gomori A, Moriya M, Ito M, Iwaasa H, Matsuda M, Feng Y, Shen Z, Mars A et al. 2005 Antiobesity effect of a melaninconcentrating hormone 1 receptor antagonist in diet-induced obese mice. Endocrinology 146 3080-3086. (doi:10.1210/en.2004-1150)

Mendez-Andino JL \& Wos JA 2007 MCHR-1 antagonists: what is keeping most research programs away from the clinic? Drug Discovery Today $\mathbf{1 2}$ 972-979. (doi:10.1016/j.drudis.2007.08.010) 
Messager S, Chatzidaki EE, Ma D, Hendrick AG, Zahn D, Dixon J, Thresher RR, Malinge I, Lomet D, Carlton MB et al. 2005 Kisspeptin directly stimulates gonadatropin-releasing hormone release via G-protein-coupled receptor 54. PNAS 102 1761-1766. (doi:10.1073/ pnas.0409330102)

Messina MA, Boersma G, Overton JM \& Eckel LA 2006 Estradiol decreases the orexigenic effect of melanin-concentrating hormone in ovariectomized rats. Physiology \& Behavior 88 523-528. (doi:10.1016/j. physbeh.2006.05.002)

Morens C, Norregaard P, Receveur JM, van Dijk G \& Scheurink AJ 2005 Effects of $\mathrm{MCH}$ and $\mathrm{MCH} 1$-receptor antagonist on (palatable) food and water intake. Brain Research 1062 32-38. (doi:10.1016/j.brainres.2005. 09.005)

Morton GJ, Mystkowski P, Matsumoto AM \& Schwartz MW 2004 Increased hypothalamic melanin-concentrating hormone gene expression during energy restriction involves a melanocortin-independent estrogen-sensitive mechanism. Peptides 25 667-674. (doi:10.1016/ j.peptides.2004.02.007)

Morton GJ, Cummings DE, Baskin DG, Barsh GS \& Schwartz MW 2006 Central nervous system control of food intake and body weight. Nature 443 289-295. (doi:10.1038/nature05026)

Murray JF, Adan RAH, Walker R, Baker BI, Thody AJ, Nijenhuis WAJ, Yukitake J \& Wilson CA 2000a Melanin-concentrating hormone, melanocortin receptors and regulation of luteinising hormone release. Journal of Neuroendocrinology 12 217-223. (doi:10.1046/j.1365-2826. 2000.00440.x)

Murray JF, Baker BI, Levy A \& Wilson CA 2000b The influence of gonadal steroids on pre-pro melanin-concentrating hormone mRNA in female rats. Journal of Neuroendocrinology 12 53-59. (doi:10.1046/j.13652826.2000.00425.x)

Murray JF, Hahn JD, Kennedy AR, Small CJ, Bloom SR, Haskell-Luevano C, Coen CW \& Wilson CA 2006 Evidence for a stimulatory action of melaninconcentrating hormone on luteinizing hormone release involving $\mathrm{MCH} 1$ and melanocortin-5 receptors. Journal of Neuroendocrinology $\mathbf{1 8}$ 157-167. (doi:10.1111/j.1365-2826.2005.01397.x)

Muschamp JW \& Hull EM 2007 Melanin concentrating hormone and estrogen receptor- $\alpha$ are coextensive but not co-expressed in cells of male rat hypothalamus. Neuroscience Letters 427 123-126. (doi:10.1016/j. neulet.2007.09.031)

Mystkowski P, Seeley RJ, Hahn TM, Baskin DG, Havel PJ, Matsumoto AM, Wilkinson CW, Peacock-Kinzig K, Blake KA \& Schwartz MW 2000 Hypothalamic melanin-concentrating hormone and estrogen-induced weight loss. Journal of Neuroscience 20 8637-8642.

Nair SG, Adams-Deutsch T, Pickens CL, Smith DG \& Shaham Y 2009 Effects of the $\mathrm{MCH} 1$ receptor antagonist SNAP 94847 on high-fat food-reinforced operant responding and reinstatement of food seeking in rats. Psychopharmacology 205 129-140. (doi:10.1007/s00213-009-1523-6)

Oftedal OT 2004 Lactation, land mammals, species comparisons. In Encyclopaedia of Animal Science, pp 562-564. Eds WG Pond\& AW Bell. New York: Marcel Dekker, Inc.

Pasquali R, Pelusi C, Genghini S, Cacciari M \& Gambineri A 2003 Obesity and reproductive disorders in women. Human Reproduction Update $\mathbf{9}$ 359-372. (doi:10.1093/humupd/dmg024)

Pissios P 2009 Animal models of MCH function and what they can tell us about energy balance. Peptides 30 2040-2044. (doi:10.1016/j.peptides. 2009.05.002)

Qu D, Ludwig DS, Gammeltoft S, Piper M, Pelleymounter MA, Cullen MJ, Mathes WF, Przypek R, Kanarek R \& Maratos-Flier E 1996 A role for melanin-concentrating hormone in the central regulation of feeding behaviour. Nature 380 243-247. (doi:10.1038/380243a0)

Rance NE, Krajewski SJ, Smith MA, Cholanian M \& Dacks PA 2010 Neurokinin B and the hypothalamic regulation of reproduction. Brain Research 1364 116-128. (doi:10.1016/j.brainres.2010.08.059)

Rodriguez M, Beauverger P, Naime I, Rigue H, Ouvry C, Souchand S, Dramaint S, Nagel N, Suply T, Audinot V et al. 2001 Cloning and molecular characterisation of the novel human melanin-concentrating hormone receptor MCH2. Molecular Pharmacology $60632-639$.

Rondini TA, Donato J Jr, de Cruis Rodrigues B, Bittencourt JC \& Elias CF 2010 Chemical identity and connections of medial preoptic area neurons expressing melanin concentrating hormone during lactation. Journal of Chemical Neuroanatomy 39 51-62. (doi:10.1016/j.jchemneu. 2009.10.005)
Saito Y, Nothacker HP, Wang Z, Lin SH, Leslie FM \& Civelli O 1999 Molecular characterisation of the melanin-concentrating hormone receptor. Nature 400 265-269. (doi:10.1038/22321)

Saito Y, Cheng M, Leslie FM \& Civelli O 2001 Expression of the melaninconcentrating hormone $(\mathrm{MCH})$ receptor mRNA in rat brain. Journal of Comparative Neurology 435 26-40. (doi:10.1002/cne.1191)

Sakamaki R, Uemoto M, Inui A, Asakawa A, Ueno N, Ishibashi C, Hirono S, Yukioka H, Kato A, Shinfuku N et al. 2005 Melanin-concentrating hormone enhances sucrose intake. International Journal of Molecular Medicine 15 1033-1039.

Santollo J \& Eckel LA 2008 The orexigenic effect of melanin-concentrating hormone $(\mathrm{MCH})$ is influenced by sex and stage of estrous cycle. Physiology \& Behavior 93 842-850. (doi:10.1016/j.physbeh.2007.11.050)

Santollo J \& Eckel LA 2013 Oestradiol decreases melanin-concentrating hormone $(\mathrm{MCH})$ and $\mathrm{MCH}$ receptor expression in the hypothalamus of female rats. Journal of Neuroendocrinology 25 570-579. (doi:10.1111/ jne.12032)

Schéle E, Fekete C, Egri P, Füzesi T, Palkovits M, Keller É, Liposits Z, Gereben B, Karlsson-Lindahl L, Shao R et al. 2012 Interleukin-6 receptor $\alpha$ is co-localised with melanin- concentrating hormone in human and mouse hypothalamus. Journal of Neuroendocrinology 24 930-943. (doi:10.1111/j.1365-2826.2012.02286.x)

Schneider JE 2004 Energy balance and reproduction. Physiology \& Behavior 81 289-317. (doi:10.1016/j.physbeh.2004.02.007)

Segal-Lieberman G, Bradley RL, Kokkotou E, Carlson M, Trombly DJ, Wang X, Bates S, Myers MG, Flier JS \& Maratos-Flier E 2003 Melaninconcentrating hormone is a critical mediator of the leptin-deficient phenotype. PNAS 100 10085-10090. (doi:10.1073/pnas.1633636100)

Segal-Lieberman G, Rubinfeld H, Glick M, Kronfeld-Shaw N \& Shimon I 2006 Melanin concentrating hormone stimulates human growth hormone secretion: a novel effect of $\mathrm{MCH}$ on the hypothalamic-pituitary axis. American Journal of Physiology. Endocrinology and Metabolism 290 E982-E988. (doi:10.1152/ajpendo.00138.2005)

Shimada M, Tritos NA, Lowell BB, Flier JS \& Maratos-Flier E 1998 Mice lacking melanin-concentrating hormone are hypophagic and lean. Nature 396 670-674. (doi:10.1038/25341)

Sita LV, Elias CF \& Bittencourt JC 2007 Connectivity pattern suggests that incerto-hypothalamic area belongs to the medial hypothalamic system. Neuroscience 148 949-969. (doi:10.1016/j.neuroscienceREF77=10. 1016/S0091-3022(02)00002-X)

Small CJ, Goubillon ML, Murray JF, Siddiqui A, Grimshaw SE, Young H, Sivanesan V, Kalamatianos T, Kennedy AR, Coen CW et al. 2003 Central orexin $\mathrm{A}$ has site-specific effects on luteinizing hormone release in female rats. Endocrinology 144 3225-3236. (doi:10.1210/en.2002-0041)

Smith MS \& Grove KL 2002 Integration of the regulation of reproductive function and energy balance: lactation as a model. Frontiers in Neuroendocrinology 23 225-256. (doi:10.1016/S0091-3022(02)00002-X)

Solorzano CMB, Beller JP, Abshire MY, Collins JS, McCartney CR \& Marshall JC 2012 Neuroendocrine dysfunction in polycystic ovary syndrome. Steroids 77 332-337. (doi:10.1016/j.steroids.20REF81=10. 1006/geno.2002.6771)

Sun G, Tian Z, Murata T, Narita K, Honda K \& Higuchi T 2004 Central and peripheral immunoreactivity of melanin-concentrating hormone in hypothalamic obese and lactating rats. Journal of Neuroendocrinology 16 79-83. (doi:10.1111/j.1365-2826.2004.01124.x)

Takahashi K, Totsune K, Murakami O, Sone M, Satoh F, Kitamuro T, Noshiro T, Hayashi Y, Sasono H \& Shibaharas S 2001 Expression of melanin concentrating hormone receptor messenger ribonucleic acid in tumour tissues of pheochromocytoma, ganglioneuroblastoma and neuroblastoma. Journal of Clinical Endocrinology and Metabolism 86 369-374. (doi:10.1210/jc.86.1.369)

Tan CP, Sano H, Iwaasa H, Pan J, Sailer AW, Hreniuk DL, Feighner SD, Palyha OC, Pong S-S, Figueroa DJ et al. 2002 Melanin-concentrating hormone receptor subtypes 1 and 2: species-specific gene expression. Genomics 79 785-792. (doi:10.1006/geno.2002.6771)

Thompson RH, Canteras NS \& Swanson LW 1996 Organisation of projections from the dorsomedial nucleus of the hypothalamus: a PHA-L study in the rat. Journal of Comparative Neurology 376 143-173. (doi:10.1002/(SICI)1096-9861(19961202)376:1<143::AIDCNE9>3.0.CO;2-3)

Topologlu AK, Reimann F, Guclu M, Yalin AS, Kotan LD, Porter KM, Serin A, Mungan NO, Cook JR, Ozbek MN et al. 2009 TAC3 and TAC3R 
mutations in familial hypogonadotropic hypogonadism reveal a key role for neurokinin B in the central control of reproduction. Nature Genetics 41 354-358. (doi:10.1038/ng.306)

Tsukamura H, Thompson RC, Tsukahara S, Ohkura S, Maekawa F, Moriyama R, Niwa Y, Foster DL \& Maeda K-I 2000 Intracerebroventricular administration of melanin-concentrating hormone suppresses pulsatile luteinizing hormone release in the female rat. Journal of Neuroendocrinology 12 529-534. (doi:10.1046/j.1365-2826. 2000REF90=10.1371/journal.pone.0005361)

Vaughan JM, Fisher WH, Hoeger C, River I \& Vale W 1989 Characterisation of melanin-concentrating hormone from rat hypothalamus. Endocrinology 125 1660-1665. (doi:10.1210/endo-125-3-1660)

Viale A, Kerdelhue B \& Nahon JL 1999 17- $\beta$ Estradiol regulation of melaninconcentrating hormone and neuropeptide-E-I contents in cynomolgus monkeys: a preliminary study. Peptides 20 553-559. (doi:10.1016/ S0196-9781(99)00007-8)

Vitale ML, Chicchio SR \& Tramezzani JH 1993 Serotonin, a neurotransmitter involved in the regulation of luteinising hormone release. Endocrine Reviews 14 480-493. (doi:10.1210/er.14.4.480)

Wakabayashi Y, Nakada T, Murata K, Ohkura S, Mogi K, Navarro VM, Clifton DK, Mori Y, Tsukamura H, Maeda K-U et al. 2010 Neurokinin B and dynorphin $\mathrm{A}$ in kisspeptin neurons of the arcuate nucleus participate in generation of periodic oscillation of neural activity driving pulsatile gonadotropin-releasing hormone secretion in the goat. Journal of Neuroscience 30 3124-3132. (doi:10.1523/JNEUROSCI.5848-09.2010)

Wang S, Behan J, O'Neill K, Weig B, Fried S, Laz T, Bayne M, Gustafson E \& Hawes B 2001 Identification and pharmacological characterisation of a novel human melanin concentrating hormone receptor $\mathrm{MCH}-\mathrm{R} 2$. Journal of Biological Chemistry 276 34664-34670. (doi:10.1074/jbc. M102601200)

Ward DR, Dear FM, Ward IA, Anderson SI, Spergel DJ, Smith PA \& Ebling FJP 2009 Innervation of gonadotropin-releasing hormone neurons by peptidergic neurons conveying circadian or energy balance information in the mouse. PLOS ONE 4 1-9. (doi:10.1371/journal.pone. 0005361)

Williamson-Hughes PS, Grove KL \& Smith MS 2005 Melanin-concentrating hormone $(\mathrm{MCH})$ : a novel neural pathway for regulation of $\mathrm{GnRH}$ neurons. Brain Research 1041 117-124. (doi:10.1016/j.brainres.2004. 11.066)

Wu M, Dumalska I, Morozoova E, van den Pol A \& Alreja M 2009 Melaninconcentrating hormone directly inhibits $\mathrm{GnRH}$ neurons and blocks kisspeptin activation, linking energy balance to reproduction. PNAS 106 17227-17222. (doi:10.1073/pnas.0908200106)

Yang Y, Zhou L-B, Liu S-Q, Tang J-F, Li F-Y, Li R-Y, Song H-D \& Chen M-D 2005 Expression of feeding-related peptide receptors mRNA in GT1-7 cell line and roles of leptin and orexins in control of GnRH secretion. Acta Pharmacologica Sinica 26 976-981. (doi:10.1111/j.1745-7254. 2005.00118.x)

Yu WH, Kimura M, Walczewska A, Karanth S \& McCann SM 1997 Role of leptin in hypothalamic-pituitary function. PNAS 94 1023-1028. (doi:10.1073/pnas.94.3.1023)

Zheng $\mathrm{H}$, Patterson LM, Morrison C, Banfield BW, Randall JA, Browning KN, Travagli RA \& Berthould H-R 2005 Melanin-concentrating hormone innervation of caudal brainstem areas involved in gastrointestinal functions and energy balance. Neuroscience 135 611-625. (doi:10.1016/j.neuroscience.2005.06.055)

Received 1 October 2012

First decision 5 December 2012

Revised manuscript received 17 June 2013

Accepted 23 July 2013 